\title{
Covid-19 pandemic and Foreign Trade: A Comparative Analysis in Indian Context
}

\author{
Devasish Hazarika \\ Ph.D Scholar, Mahatma Gandhi Central University,Motihari,Bihar \\ Email ID: hdevasish@gmail.com
}

\begin{abstract}
:
Covid-19 and lockdown as its preventive measure hit Indian Economy at a worst time. The trade performances prior to the pandemic was not satisfactory and held a decreasing trend in terms of the previous periods. In this paper an honest attempt has been made to analyse international trade as an Engine of Economic Growth, that is, its importance or significance in Economic Growth processes as well as to assess the comparative trend in international trade before and after the pandemic situation. This paper is based on secondary data. The paper is essentially a descriptive and analytical in nature. Statistical tools like graph, table etc are used for better understanding. The foreign trade is found to be diminishing in its share while analysing the data of last 10 years prior to the pandemic and nationwide lockdown. The merchandise trade surplus in June 2020 was estimated at USD 0.79 billion as against deficit of USD 15.28 billion in June, 2019. The trade balance for service is estimated at USD 6.83 on $15^{\text {th }}$ July,2020. India recorded first trade surplus since January, 2002.
\end{abstract}

Keywords: Foreign Trade, Pandemic, Economic Growth, Merchandise Trade, Trade Surplus, Trade Deficit.

\section{Introduction:}

A pneumonia of unknown cause which was later named by WHO on $11^{\text {th }}$ February 2020, as covid-19 also known as Corona Virus originating from a Latin word 'corona' meaning crown was first detected in Wuhan city of China as reported to WHO country office of China on $31^{\text {st }}$ December 2019. This virus spread all over the world for which it is regarded as a global pandemic and a declaration of public health emergency of international concern had been called forth on $30^{\text {th }}$ January 2020. As a preventive measure to slower the pace of its spread many countries followed the example of China in the aspect like Lockdown in which India was also not an exception. In the prolonged lockdown both negative demand and supply shock prevailed in the economies across the world including Indian Economy. The prolonged lockdown gave a massive hit in case of foreign trade of India which is attempted to be analysed in this paper keeping aside the other evil consequences of it in Indian economy. The paper tries to represent International Trade as an Engine of Growth and the impact of
Covid-19 on foreign trade of India with a comparative analysis based on time series data.

\section{Review of literature and Research Gap:}

To be specific the macro economic effects of covid-19 pandemic is all about demand and supply shocks. According to many economists in this pandemic both negative demand and supply shocks prevailed in the world economy. Richard Baldwin and Eiichi Tomiura in their study about the trade impact of Covid-19 rightly mentioned that both supply shock and demand shock will impact international trade in goods and services. They have assumed covid-19 as 'contagious' in economic sense as it is in case of medical sciences. They have analysed the demand and supply shocks, GDP growth rate , impact on manufacturing and exports of six largest economy of the world viz China, Korea, Italy, Japan, US and Germany where they reported cases of covid-19 positives is maximum till March 2,2020 . The study was carried forward on the basis of secondary data using charts and diagrams which is empirical in nature. 
It is descriptive and analytical. The study found that manufacturing sector gets a triple hit via direct supply disruptions, direct supply shocks and demand disruptions due to fall in the aggregate demand. In a study carried forward by George Verikios, Maura Sullivan, Pane Stojanovski, James Giesecke and Gordon Woo on global economic effects of pandemic influenza where they used susceptible- infected- recoveredepidemiological model to a detailed, quarterly computable general equilibrium model found that global economic activities will be massively affected by pandemic under the assumption of ceteris paribus. The regions which are more closely related to or interlinked with the world economy that is which are open economies experience a greater hit than the lower integrated economies. Fernando Leibovici and Ana Maria Santacreu in their study area - International trade of essential goods during a pandemic, have taken the help of multi-country, multisector model with essential and nonessential goods. They have studied the role of international trade of essential goods in reducing or boosting the impact of the pandemic. They have come to the finding that the effects depend on the trade imbalances of a country, that is, net exporters are relatively less worse off and net importers of these goods are relatively more worse off. In a study on the global supply chain in the pandemic carried forwarded by Bartheleme Bonadio, Zhen Huo, Andrei A Levchenko, Nitya Pandalai Nayar where they attempted to study the role of global supply chains on GDP growth for 64 countries during the time of covid-19 pandemic used quantitative framework and methods developed by Huo, Levchenko and Pandalai Nayar (2020). They have found that the average real GDP goes on decreasing due to the negative global supply shock which they quantified as $-31.5 \%$ out of which $-10.7 \%$ is expected to be transmitted through global supply chain. Felipe Benguria and
Alan M Taylor studied on the study area of financial crises in association with international trade where they put a fundamental question- "Are financial crises a negative shock to demand or negative shock to supply"? To find the answer they have taken the help of a simple small open economy model and also statistical tools for empirical time series analysis. They found that import contracts and export remains steady and even rise and there occurs a depreciation of real exchange rates. Jose Garcia Solanes, Jusus Rodriguez Lopez and Joe Luis Torres examined demand shocks and international trade balance dynamics where they used SAVR model to identify three different shocks: real supply shocks, real demand disruptions and nominal shocks. Estimates reveal the fact that most of the changes in trade imbalances are explained by the real demand shocks and nominal shocks are of a limited role. They further found the demand policies to be more responsible for trade imbalances.

\section{Objectives:} objectives:

This paper sets the following

1. To analyse international trade as an Engine of Growth.

2. To provide a comparative analysis on International trade of India on the basis of the pre-pandemic and post-pandemic situations.

\section{Methodology:}

In this study, the analysis of international trade as an engine of growth and the comparative analysis on international trade of India on the basis of the pre-pandemic and post-pandemic situations have been studied on the basis of the secondary data. Secondary data was collected from official publications like Economic Survey and the websites of GOI, some relevant books, journals, reports, periodicals, newspapers 
etc. The present study is both descriptive and analytical in nature.

\section{International Trade as an Engine of Growth:}

International trade plays a vital role in the economic growth process of a country. We have witnessed from the LPG policy, that is, Liberalization, Privatization and Globalization that how the economic growth trend of India had undergone some drastic changes after the implementation of such policy. The GDP growth rate under restrictive trade practices was $1.9 \%$ in the year 1990. At that time India was facing BOP deficit and most importantly current account deficits. Just after undertaking Economic reforms in the year 1991 India had experienced a change in the trend of economic growth rate. The importance of international trade on Economic Growth can be assessed with the help of the TradeGDP ratio. The Trade-GDP ratio is calculated by dividing the aggregate values of import and export by the Gross Domestic Product of a country for a specific time period. So, it shows the relative share of international trade to GDP of a country. Let us consider the following figure 1 that represents the Trade-GDP ratio of India from 1960 to 2019.

Figure 1: Trade (as Percentage of GDP) in India

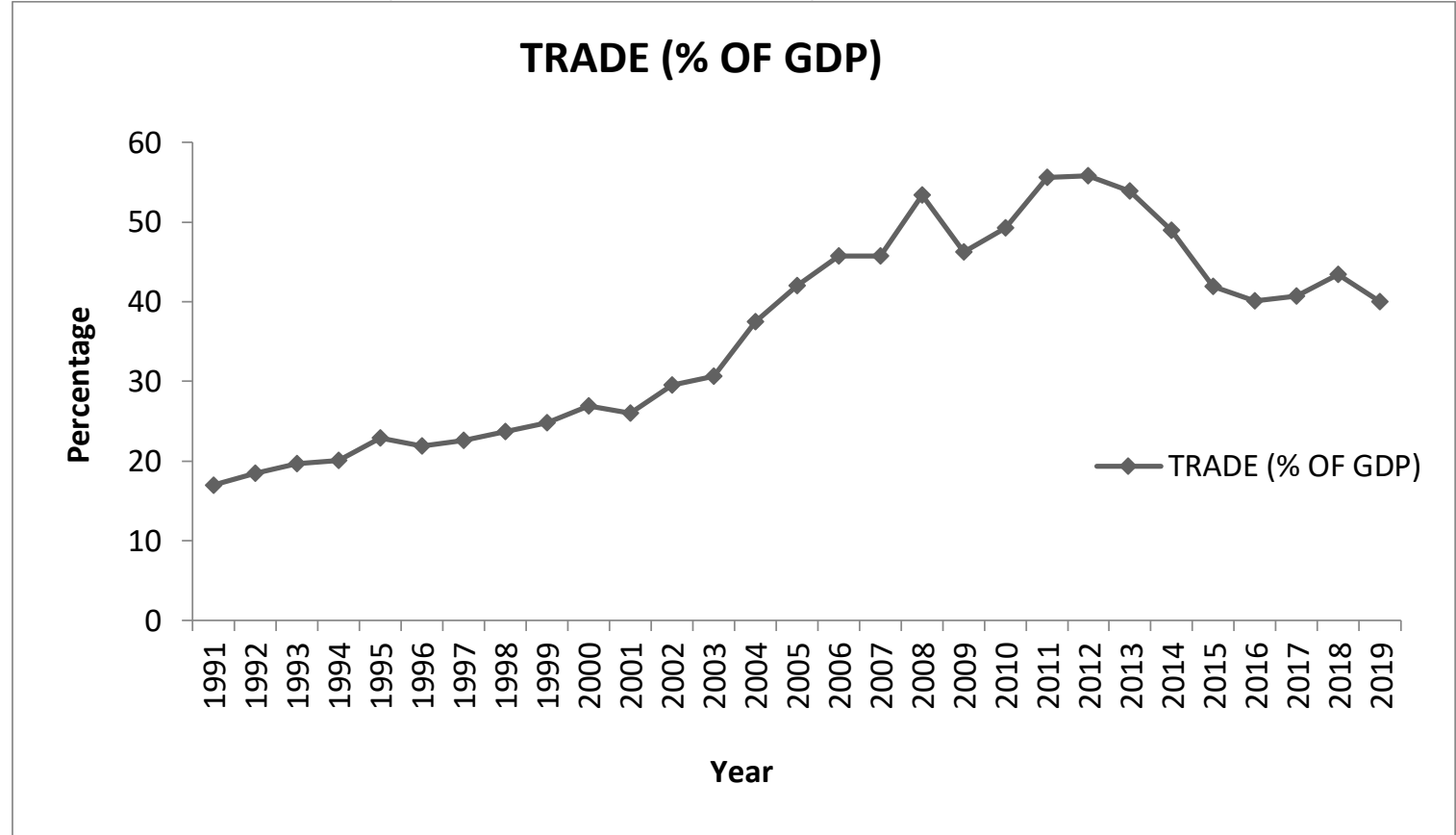

Source: World Bank development indicator

The figure above shows an upward trend as a whole though there is some sort of fluctuations. Such an upward sloping curve reveals the validity of the statement "International trade as an Engine of Growth". This is because, the share of GDP to Gross Domestic Product of the nation has a positive correlation in an aggregate level even though there is a negative relationship in some years which are negligible.

\section{Foreign Trade of Indian Economy During Pre Pandemic Era at a glance:}

India has been experiencing a downturn in its exports for along time now. Even before the pandemic hits the world economy. Trade wars between the US and China, inward looking and protectionist economies, led by Europe, and global tensions had resulted in an export slump and the pandemic has only added further to India's exports woes. 
India exported US\$322 billion of goods and services in 2018, while imports were US\$17 billion (source from WITS). In 2017, the corresponding figures were US\$483 and US\$ 524 billion, respectively. Services accounted for approximately 36 percent of the total, and the country a rank of $13^{\text {th }}$ among 133 countries in 2017. Exports of India have grown at an annual average of 1.6 per cent, while non- oil exports have grown at 2.8 per cent. India's merchandise exports for the year 2018-19 was US\$ 330.07 billion (provisional estimate, department of Commerce, Government of India , 2019), surpassing the earlier peak of US\$ 314.4 billion achieved in 2013-14. In terms of destination, USA is India's largest trading partner with a share of 16 percent in 2018, while India's imports from China are the largest, with a share of nearly 15 percent. India's exports to the USA include diamonds, pharmaceuticals, machinery, mineral fuels and vehicles, while its export to China consists of organic chemicals, cotton, plastics etc. India's imports from China comprise of telephone, cellular phone, diodes etc.

Outbreak of COVID-19 and Its Impact on India's Foreign Trade : Disruption in foreign trade in India is so huge that it surpasses the damage brought about by Global financial crisis in 2008 .

In imports, the dependence of India on China is huge. Nearly $55 \%$ of electronics imported by India originated from China. This imports have already slowed down to $45 \%$ in light of corona virus outbreak and subsequent lockdown. The toll on the pharmaceutical industry is of significant concern for India, mainly as $\mathbf{7 0 \%}$ of Active Pharmaceutical Ingredients (APL) Are imported from China. Again, China is India's third largest export partner of raw materials like organic chemicals, mineral fuels, cotton etc. and a lockdown of the countries is likely to lead to a substantial trade deficit for India.

India's overall exports (Merchandise and services combined) for recent three months- March, April, May 2020 are shown as follows:

\section{Merchandise trade Exports:}

- According to the data released by RBI, Export in March 2020 were USD 21.41 bilion, as compared to USD 32.72 billion in March 2019, exhibiting a negative growth of (-) $34,57 \%$

- Except for Iron ore, which registered a growth of $58.43 \%$, all other commodities have registred negative growth in March 2020 vis-à-vis March 2019.

Major commodities which recorded negative growth rate during March 2020 vis-à-vis March 2019 can be shown through the following table:

Table: (1)

\begin{tabular}{|l|l|}
\hline \multicolumn{1}{|c|}{ Commodities } & \multicolumn{1}{|c|}{ y/y Fall in Export(\%) in } \\
March & \\
\hline Oil meals & 69.85 \\
\hline Meat, diary, \& Poultry Products & 45.48 \\
\hline Engineering goods & 42.32 \\
\hline Gems \& jewellery & 41.05 \\
\hline
\end{tabular}




\begin{tabular}{|l|l|}
\hline Tea & 33.74 \\
\hline Rice & 28.28 \\
\hline Petroleum products & 31.12 \\
\hline Non petroleum and non gems and jewellery & 34.19 \\
\hline Organic and inorganic chemicals & 32.88 \\
\hline Cotton yarn, handloom product etc. & 32.16 \\
\hline
\end{tabular}

Source: ICC

- Exports in April 2020 were USD 10.36 billion as compared to USD26.07billion in April 2019.

- In the month of June, Exports were USD21.9billion, as compared to USD 25.01billion in June 2019, exhibiting a negative growth of () $12.41 \%$.

\section{Imports:}

- According to RBI data, Imports in March 2020 were USD31.16billion which was $23.72 \%$ lower in rupee terms over import of USD43.72billion in March 2019. In June, imports were USD221.11billion which was $42.85 \%$ lower in rupee terms over imports of USD40.29billion in June 2019.

- Oil imports in June 2020 were USD4.93billion which was $51.24 \%$ lower in rupee terms compares to 11.03billion in June 2019.

\section{Trade in Service: Exports (Receipts)}

- As per the latest press release by RBI dated June 2020, exports in April 2020 were USD 16.45bilion registering a negative growth of (-) $8.92 \%$ in dollar terms. In May 2020 it were USD 16.77billion registering a negative growth of (-)10.24\% in dollar terms.

Besides due to the ongoing pandemic, travel restrictions, and the countrywide lockdown have brought the entire tourism industry to a standstill. India's total Foreign Tourist Arrivals (FTA) stood at 10.9 million and the foreign exchange earnings stood at Rs 210,971 crore during 2019, with Maharashtra , Tamil Nadu, Uttar Pradesh and Delhi accounting for about $60 \%$ of Foreign Tourist Arrivals (FTA). However, due to travel restrictions in for over $80 \%$ countries, India's domestic as well as foreign travel and tourism industry is expected to witness a sharp negative impact in 2020.

India is a service lade economy, and the US and Europe are the major destinations of India's service exports. More than $3 / 4^{\text {th }}$ of India's service export from the IT industry would be effected given the vast spread of COVID-19 in these regions. India's major IT companies which are software exporters, are likely to be affected due to the reduced technology spending by companies in the US and Europe during the lockdown in a bid to prevent the spread of the disease. India's exports to it's major trading partners have been negatively impacted due to the lockdown in several countries such as China, Italy, and Germany.

\section{Imports:}

- As per the latest press release by RBI dated July2020, Imports in May 2020 were 9.94billion registering a negative growth og (-)20.45\% in dollar terms.

\section{Trade Balance:}


- Merchandise: The trade surplus for June 2020 was estimated at USD0.79bilion as against the deficit of USD15.28billion in June 2019.

- Service: As per RBI's press release dated $15^{\text {th }}$ July 2020 , the trade balance in service for May 2020 is estimated at USD6.83 billion.

- Overall Trade Balance: Taking merchandise and services together, overall trade surplus for April-June 2020-21 is estimated at USD 11.70 billion as compared to the deficit of USD26.32 billion in April-June 2019-20.

- It is remarkable that India posted its first trade surplus since January 2002. It is only because of COVID-19 led drop in demand for crude oil gold and other merchandise goods. Gold import which is the second largest in the import basket after crude oil, contracted over $77 \%$, while petroleum and crude oil contracted over $55 \%$.

Measures that government and RBI has taken to Combat the harmful effect on India's Foreign trade:

Measures taken by government:

1)On $12^{\text {th }}$ May, PM Modi has announced a new economic package named "Atmanirbhar Bharat Abhiyan" through which he argued the need to disincentivise imports of goods which can be produced domestically and enhancement of export.

2) Recently, the government has announced an incentive programme of Rs 10,000 crore for spurring domestic API production and in the short- term, imports of API could also be considered for ramping up manufacturing for domestic use and exports.

3) Government has also extended the current Foreign Trade Policy (FTP ) to the end of the financial year 2020. With more time hand this allows the government to revisit its stance and prepare for the post covid world wherein exporters would require much more support than just export incentive schemes.

- A key issue facing exporters is credit access. The extension of the interest subvention scheme available for MSME exporters could be announced immediately. Further, to tide over the current crisis situation, the scheme could be extended to all exporters as well as those manufacturing mainly for exports. For import related to exports, banks need to priorities credit documents and provide special cash credit funding.

Measures taken by RBI:

1)During this situation exporters facing genuine difficulties such as delay or postponement of orders and delay in realization of bills, which adversely affecting their production and realization cycles. That's why RBI has decided to extend a line credit of 15000 crore to Export- Import Bank of India ( EXIM Bank) for a period 90 days to a maximum period of one year so as to enable it to avail a dollar swap facility to meet its foreign exchange requirements.

2)RBI also announce its decision to extend the time period for completion of remittances against normal imports into India from the date of shipment for such import made on or before July 31 .

\section{Conclusion:}

Like global economy, Devastation created by Covid 19 pandemic is a tough challenge for Indian economy. It is necessary to take careful and well planned steps to overcome this situation - moreover, while the gloom and doom surrounding COVID-19 is palpable, the crisis might also throw up some great opportunities for India. India should also focus on them and take well plan 
and preparation to utilize this opportunities

\section{References:}

[1] Silva A Julie(2008). International trade and changing demand for skilled workers in high tech manufacturing

[2] Chen Bowen and Villoria B Nelson(2019). Climate shocks,food price stability and international trade: Evidence from 76 maize markets in 27 net- importing

[3] countries.

[4] https://doi.org/10.1088/1748-9326/aafo7f

[5] Solanes Garcia Jose, Lopez Rodriguez Jesus, Torres Luis Jose(2010). Demand shocks abd trade balance dynamics

[6] Distefano Tiziano, Laio Francesco,Schiavo Stafeno(2017). Shock transformation in the international food trade network. A data driven analysis. 